\title{
DYNAMIC ANALYSIS OF AN EXISTING ARCH RAILWAY BRIDGE ACCORDING TO EUROCODES
}

\author{
R. OLESZEK ${ }^{1}$, W. RADOMSKI ${ }^{2}$
}

\begin{abstract}
Modern regulations concerning railway bridges are based on the approach of structural dynamics, which is described in PN-EN standards. This paper presents the results of theoretical dynamic analysis of the HSLM-A train set loading on the structure of a pre-stressed concrete arch bridge - the first railway bridge of its type which was built in Poland (completed in 1959). The recommendations of PN-EN have been followed and modal analysis was carried out to define the sensitivity of the structure to chosen eigenforms. Additionally the paper presents a course of calculations and the conclusions obtained from the analysis of displacements, accelerations, and bending moments induced in the structure through a simulated passage of a high-speed train in the context of the requirements of PN-EN Standards. The conclusions from the current calculations can be used for dynamic analysis of bridges of similar structural solutions.
\end{abstract}

Keywords: dynamic response, high-speed trains, prestressed concrete, numerical model, HSLM, dynamic factor

\section{INTRODUCTION}

Contemporary railway engineering regulations $[1 \div 3,8]$ are based on PN-EN $[6,7]$ in which the dynamic nature of loading is taken into consideration on the basis of the dynamic analysis of the structure's response to a simulated moving load. This analysis consists of determining the direct processes of deformation and distributions of internal forces under loading caused by high-speed trains simulated by High Speed Load Models (HSLM).

\footnotetext{
${ }^{1}$ MSc., Eng., Warsaw University of Technology, Faculty of Civil Engineering, Al. Armii Ludowej 16, 00-637 Warsaw, Poland, e-mail: r.oleszek@il.pw.edu.pl

2 Prof., DSc., PhD., Eng., Łódź University of Technology, Faculty of Civil Engineering, Department of Geotechnics and Engineering Structures, Al. Politechniki 6, 90-924 Łódź, Poland, e-mail: wojciech.radomski@p.lodz.pl, w.radomski@il.pw.edu.pl
} 
This paper presents the results of theoretical dynamic analysis of HSLM-A loading on the structure of a pre-stressed concrete arch bridge, the first railway bridge of its type built in Poland (completed in 1959), in accordance with the requirements of PN-EN standards. This computational approach is similar to the approaches used by other researchers [10, 12, 17-20, 22, 23]. Due to its exploratory nature, the results of this analysis can be used in the design of the contemporary arch bridges, or in evaluating existing bridges of this type in terms of their suitability for new operating conditions. In other words, this paper allows us to answer the question of how the existing bridge, at nearly 60 years old, can be adapted to contemporary operating conditions, especially to the presence of high speed trains. The individual analysis presented herein can also be of more general meaning in practice.

\section{BRIDGE DESIGN DESCRIPTION}

The bridge over the river Orz in Gucin (Fig. 1) is the first railway arch bridge in Poland of prestressed post-tensioned concrete structure, designed in the period of 1955-1956 by a design team led by Prof. Zbigniew Wasiutyński, and later constructed in 1956-1959 [21].

a)

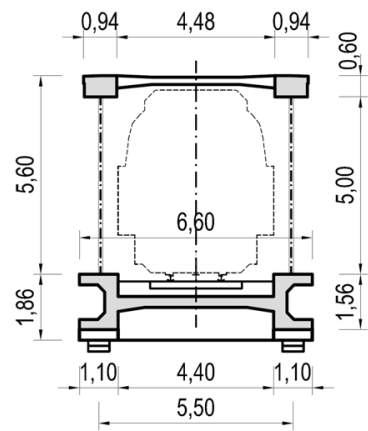

b)

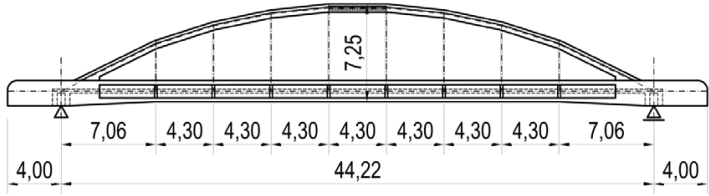

Fig. 1. Railway bridge over the river Orz in Gucin, Poland: a) cross-section, b) side view

The bridge has the effective design span of $44.22 \mathrm{~m}$ and an overall length of $52.22 \mathrm{~m}$. The C-shaped longitudinal girders are of varying heights, $1.56 \div 1.76 \mathrm{~m}$, in width of $1.10 \mathrm{~m}$ and web thickness of $0.38 \mathrm{~m}$ with $0.30 \mathrm{~m}$ top flange and $0.28 \mathrm{~m}$ thick bottom flange. At the supports at $4.30 \mathrm{~m}$ length, the channel section changes linearly to a $1.10 \times 1.86 \mathrm{~m}$ box section. The main girders are suspended from the concrete arches measuring $0.92 \div 0.94 \times 0.60 \mathrm{~m}$ using $120 \times 40 \mathrm{~mm}$ flat irons. The arches are 
braced at the crowns with $0.20 \mathrm{~m}$ tie plates. The pre-stressed concrete deck slab is $0.30 \mathrm{~m}$ thick, and the concrete members are made of concrete with $R_{w}=400 \mathrm{kG} / \mathrm{cm}^{2}$ and Freyssinet prestressing steel tendons. The structure is designed for the NC load class (standard heavy train) according to $[4,5]$. The dynamic character of the standard load NC [4] was expressed in the design calculations by the standard dynamic coefficient $\varphi_{\text {proj }}=1,212$.

\section{PRINCIPLES OF DYNAMIC ANALYSIS ACCORDING TO PN-EN}

The principles of dynamic analysis given by Eurocodes (PN-EN 1990:2004 [6], PN-EN 19912:2007 [7]) are valid for train velocities of up to $v<350 \mathrm{~km} / \mathrm{h}$ and include:

- modal analysis, which allows us to estimate the sensitivity of the structure to select forms of vibration as well its damping characteristics, and which can be applied for train velocity $v<200$ $\mathrm{km} / \mathrm{h}$,

- time-history response analysis, which allows us to use an integration of motion equations to determine the response of the structure to the stress of high velocity trains of the standard HSLM type.

In Eurocodes [6,7], the dynamic nature of the live load can be analysed via the use of two different methods. The first is the quasi-static method, concerning loading caused by the standard LM-71 train type multiplied by the dynamic coefficient $\Phi$, with the values depending on the quality of maintenance of the railway track. The second can be achieved using the above-mentioned time analysis. Dynamic analysis of some relatively simple structures can be limited to the modal analysis only when train velocity $v<200 \mathrm{~km} / \mathrm{h}$. The PN-EN [7] standard includes detailed conditions concerning situations when time analysis is required. When train speed $v>200 \mathrm{~km} / \mathrm{h}$, time analysis is obligatory.

According to PN-EN [6, 7], dynamic analysis of bridge structures should be performed for determining the following factors:

- sensitivity of the structure to transversal vibration, when the condition $f_{h m i n}>f_{h 0}=1,20 \mathrm{~Hz}$ is met ( $f_{\text {hmin }}$ is the first frequency of the transversal vibration of the bridge superstructure),

- sensitivity of the structure to torsional vibration using condition $n_{T}>1,2 \cdot n_{0}$ (non-sensitive structure), where $n_{T}$ is the first frequency of the torsional vibration of the structure subjected to dead loads only, $n_{0}$ is the first frequency of its bending vibration under dead loads only, 
- comfort of train passengers resulting from vertical acceleration $b_{v}$ of the railway car $\left(b_{v}=1.0\right.$ $\mathrm{m} / \mathrm{s}^{2}-$ very good comfort, $b_{v}=1.3 \mathrm{~m} / \mathrm{s}^{2}-\operatorname{good}, \quad b_{v}=2.0 \mathrm{~m} / \mathrm{s}^{2}-$ sufficient) - these comfort levels can be estimated in a simplified way based on the limitations of static vertical deflections of the bridge superstructure $u_{z \max } \leq \delta_{\text {dop }}=\delta_{\text {dop }}(v)$ under the standard train LM-71 type multiplied by the dynamic coefficient $\Phi$ and the classified coefficient of the vertical load $\alpha_{k}=1,0$,

- comparison of the dynamic analyses performed using the above-mentioned methods (i.e., modal and time-history analyses) to determine the dynamic effects expressed by $\varphi^{\prime} d y n$ and the real value of the dynamic coefficient $\Phi=1+\varphi^{\prime}$ 'dyn,

- to check whether the real train or the standard train model HSLM produce values of internal forces in the structure not bigger than those produced by the static load of the standard LM-71 train type multiplied by the dynamic coefficient $\Phi$,

- to determine the maximum values of acceleration of the arbitrary chosen point of the structure which should be less than $a_{z d o p}=3,5 \mathrm{~m} / \mathrm{s}^{2}$ due to the stability of the ballast of the tracks.

\section{STRUCTURAL DYNAMIC CALCULATIONS}

\subsection{COMPUTATIONAL MODELS USED IN THE ANALYSIS}

Computational models of the structure, differing in methods of discretization (Fig. 2), designed with SOFiSTiK FEM software, are as follows [15, 16, 19, 22]. The following symbols characterizing the numerical models are used: $\mathrm{e}-$ finite element type $\left(\mathrm{e}^{1}-\right.$ truss, bar or beam element, $\mathrm{e}^{2}-$ twodimensional element, $\mathrm{e}^{3}$ - brick element), $\mathrm{p}$ - space dimension $\left(\mathrm{p}^{1}-\right.$ straight line, $\mathrm{p}^{2}-$ plane, $\mathrm{p}^{3}-$ space).
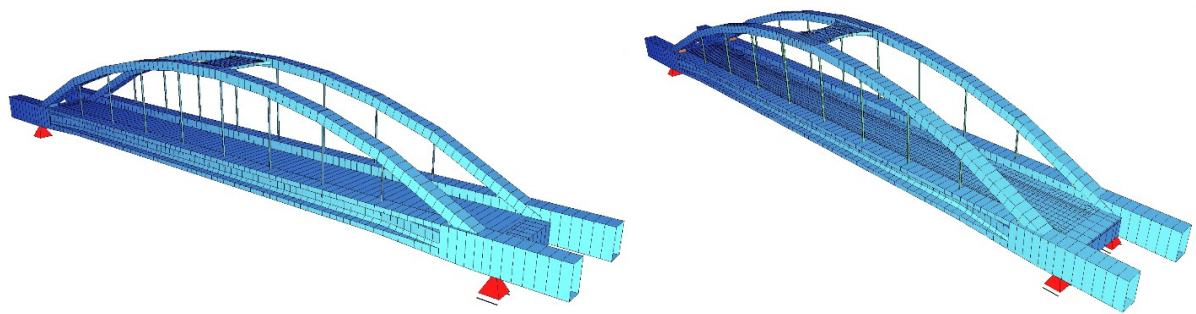

Fig. 2. Graphical presentation of the respective numerical models: a) spatial frame model - R3D-3, $\left(e^{1}, p^{3}\right)$,

b) beam and shell model, PB, $\left(\mathrm{e}^{1}+\mathrm{e}^{2}, \mathrm{p}^{3}\right)$ 
PB is a spatial beam and shell model of the structure $\left(\mathrm{e}^{1}+\mathrm{e}^{2}, \mathrm{p}^{3}\right)$. The longitudinal girders, arches, and supporting cross-beams are modelled with Timoshenko beam finite elements. The bridge deck is comprised of Mindlin-Reissner plate elements. The hangers are modelled with lattice bars. This model was used to investigate torsional modes and to calibrate the remaining representations, as well as to calibrate other models used in the analysis.

R3D-1 is a fully detailed spatial bar frame $\left(\mathrm{e}^{1}, \mathrm{p}^{3}\right)$. The longitudinal girders, arches, cross-beams, and deck (grillage constructed of longitudinal girders and cross beams) are modelled with Timoshenko beam finite elements, and the hangers with lattice bars. This model was used to investigate the torsional and bending modes.

R3D-2 is a modified spatial bar frame $\left(\mathrm{e}^{1}, \mathrm{p}^{3}\right)$. This provides a simplified representation of the structure in which the deck slab is represented by a single longitudinal beam connected by kinematic couplings with the edge girders. The hangers are represented by beam elements. This model was used to investigate the vibrations of hangers.

R3D-3 is a simplified spatial frame model $\left(\mathrm{e}^{1}, \mathrm{p}^{3}\right)$. The hangers are modelled with lattice bars. For the deck slab, a simplified discretization method was used, resulting in a model with a single longitudinal beam connected with edge girders by kinematic couplings. This model was used for the verification of the main bending modes of the structure (skipping secondary elements) and for the time-history analysis (integration of the equations of motion needed to reduce the number of dynamic degrees of freedom and size of the numerical problem).

\subsection{DYNAMIC ANALYSIS}

The modal analysis (solving of the eigenvalue problem) was carried out in the ASE module of the SOFiSTiK software. Computations of natural vibration also take into account the weight of the nonstructural components (ballast, sleepers, rails) which are converted to equivalent node weight. Because of the greater number of the degrees of freedom, the numerical analysis of the structural models was based on the modified form of the equation of motion, as follows:

$$
\begin{gathered}
\mathbf{K} \Phi_{\mathbf{u}}-\mathbf{M} \omega^{2} \Phi_{u}=0 \Rightarrow \quad \mathbf{M} \omega^{2} \Phi_{u}=\mathbf{K} \Phi_{u} \\
\left.\begin{array}{c}
\mathbf{K}=\mathbf{L} \cdot \mathbf{L}^{\mathbf{T}} \\
\mathbf{K}^{-1}=\left(\mathbf{L}^{\mathrm{T}}\right)^{-1} \cdot \mathbf{L}^{-1}
\end{array}\right\} \Rightarrow \quad \mathbf{L}^{-1} \mathbf{M} \Phi_{\mathbf{u}}=\lambda \mathbf{L}^{\mathrm{T}} \boldsymbol{\Phi}_{\mathbf{u}} \mathbf{L}
\end{gathered}
$$




$$
\left.\begin{array}{rl}
\mathbf{x} & =\mathbf{L}^{\mathbf{T}} \boldsymbol{\Phi}_{\mathbf{u}} \\
\boldsymbol{\Phi}_{\mathbf{u}} & =\left(\mathbf{L}^{\mathbf{T}}\right)^{-1} \cdot \mathbf{x}
\end{array}\right\} \Rightarrow \lambda=\frac{1}{\omega^{2}}=\mathbf{L}^{-1} \mathbf{M}\left(\mathbf{L}^{\mathbf{T}}\right)^{-1}
$$

where: $\mathbf{M}$ - mass matrix, $\mathbf{K}$ - stiffness matrix, $\omega$ - frequency, $\mathbf{\Phi}_{\mathbf{u}}-$ vector of free vibration mode, $\mathbf{L}$ - upper triangular matrix.

The calculations of the global dynamic response (ignoring the vibration of hangers) of the structure (time-history analysis) were performed in the DYNA module of SOFiSTiK. The implicit time integration method, based on the Newmark algorithm, was used for the equations of motion integration $[11-13,14,16,24]$. In these methods, the equilibrium equation refers to the analyzed point in time $\mathrm{t}+\mathrm{k} \cdot \Delta \mathrm{t}(\mathrm{k}=1,2,3 \ldots)$ and thus it takes the form (4.4). This equation is coupled with the velocity (4.5) and displacement (4.6) relationships to give the following combination of equations per the Newmark method:

$$
\begin{gathered}
M \ddot{\mathbf{u}}(\mathrm{t}+\Delta \mathrm{t})+\dot{\mathbf{C}}(\mathrm{t}+\Delta \mathrm{t})+\mathbf{K u}(\mathrm{t}+\Delta \mathrm{t})=\mathbf{P}(\mathrm{t}+\Delta \mathrm{t}), \\
\dot{\mathbf{u}}(\mathrm{t}+\Delta \mathrm{t})=\dot{\mathbf{u}}(\mathrm{t})+[(1-\delta) \ddot{\mathbf{u}}(\mathrm{t})+\dot{\delta \mathbf{u}}(\mathrm{t}+\Delta \mathrm{t})] \Delta \mathrm{t}, \\
\mathbf{u}(\mathrm{t}+\Delta \mathrm{t})=\mathbf{u}(\mathrm{t})+\dot{\mathbf{u}}(\mathrm{t}) \Delta \mathrm{t}+(\Delta \mathrm{t})^{2}\left[\left(\frac{1}{2}-\alpha\right) \ddot{\mathbf{u}}(\mathrm{t})+\alpha \ddot{\mathbf{u}}(\mathrm{t}+\Delta \mathrm{t})\right],
\end{gathered}
$$

where: $\mathbf{M}$ - mass matrix, $\mathbf{K}$ - stiffness matrix, $\mathbf{P}(t+\Delta t)$ - load vector , $\Delta t$ - integration time step, $t+$ $k \Delta t$ - analyzed time points corresponding to the equilibrium of the system, $\alpha, \delta$ - parameters corresponding to the change of acceleration in the given time step and corresponding to stability and accuracy of the method of analysis; $\mathbf{u}(t+k \Delta t)$, $\mathbf{u}(t+k \Delta t), \ddot{\mathbf{u}}(t+k \Delta t)-$ displacement vector, velocity vector, acceleration vector, respectively, in the analyzed time points.

The integration time step of $\Delta \mathrm{t}=0.005 \mathrm{sec}$. was determined per the requirement of $\Delta \mathrm{t} \leq 0.1 / f_{\max }[9$, $12,13,16]$. The mass- and stiffness-proportional (Rayleigh) damping model was applied. Damping matrix $\mathbf{C}$ is made by combining mass matrix $\mathbf{M}$ and stiffness matrix $\mathbf{K}$ according to the following formula: $\mathbf{C}=\alpha \mathbf{M}+\beta \mathbf{K}$. The coefficients of proportionality of internal and external damping ( $\alpha$ and $\beta$ ) were calculated according to the percentages of the respective eigenforms and eigenfrequencies, 
and the value of the damping ratio $\zeta=1.0 \%$ was calculated according to PN-EN [7]. With span length of $44.22 \mathrm{~m}$ (more than the limit of $30.0 \mathrm{~m}$ ), the additional damping resulting from the trainbridge interaction is $\Delta \zeta=0 \%$.Loading was modeled through sets of concentrated loads simulating the action of HSLM A1 $\div$ A10 train models [7] (Fig. 3). In this method, the load, which is constant in time, is converted to an equivalent set of nodal forces with a defined phase shift corresponding to the analyzed vehicle speed. The analysis was carried out a speed range of $160 \div 360 \mathrm{~km} / \mathrm{h}$ at $10 \mathrm{~km} / \mathrm{h}$ intervals. Static configurations ("passage") of trains were also considered. This enabled the comparison of the response to static and dynamic loading and the determination of the dynamic amplification factor as a function of deflections and running speed of HSLM train sets $\varphi=\varphi\left(v, u_{z}\right)$.

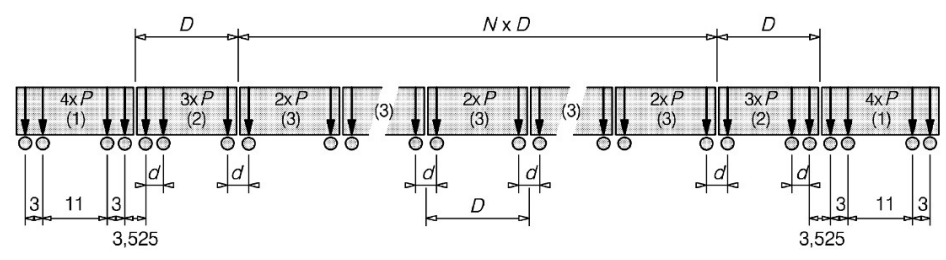

Fig. 3. High-speed train load model HSLM-A according to PN-EN [7]

\section{RESULTS OF CALCULATIONS}

\subsection{MODAL ANALYSIS}

Table 1 shows a graph presentation of the selected bending eigenform frequencies. The first two torsional eigenforms of the bridge deck vibration are presented in Table 2.

The first eigenfrequency of $f_{l}=1.56 \mathrm{~Hz}$ concerns the vibration of arches in the horizontal plane. The first (and the second of all) eigenfrequency for the bending vibration of the bridge deck in a vertical plane, identified in the simplest model (R3D-1), is $f_{2}=3.74 \mathrm{~Hz}$. It is an anti-symmetric mode shape (two half-sine wave). The value of $3.74 \mathrm{~Hz}$ slightly exceeds the lower frequency limit according to the graph in PN-EN [7]. The remaining frequencies are within the upper and lower envelopes of $9.35 \mathrm{~Hz}$ and $3.77 \mathrm{~Hz}$, respectively, thus not requiring time-history analysis for running speeds below $200 \mathrm{~km} / \mathrm{h}$ [7].

The R3D-1 model (a fully detailed spatial frame) yielded the following torsional vibration frequencies given in increasing order: $5.47 \mathrm{~Hz}, 6.44 \mathrm{~Hz}, 7.24 \mathrm{~Hz}, 8.13 \mathrm{~Hz}$. In the PB model, the 
most accurate of all, the torsional mode shapes were obtained at the following frequencies: $5.52 \mathrm{~Hz}$, $6.33 \mathrm{~Hz}, 7.30 \mathrm{~Hz}, 8.15 \mathrm{~Hz}$. The differences between these results do not exceed $2 \%$.

The R3D-2 model (with hangers modelled by beam elements) was used to determine the eigenfrequencies of the structure and of the suspension bars. A total of 100 modes was acquired. The last significant bending mode shape of free vibration of the whole structure was noted at a frequency of $f_{12}=12.30 \mathrm{~Hz}$.

The subsequent composite mode shapes (vibration of hangers, arches, crown tie plate), including the main girders' bending mode shape, occur at frequencies higher than $f_{50}=23.64 \mathrm{~Hz}$ (the fiftieth mode shape). However, such high vibration mode shapes are physically improbable, as they hardly occur in field. Moreover, they exceed the limits set forth in the regulations: $f_{\max }=20 \mathrm{~Hz}$ according to [2] and $f_{\max }=30 \mathrm{~Hz}$ according to $[6,7,12]$ ). Generally it is possible to identify only the first mode shapes of the main superstructure components. An investigation of the torsional and bending vibrations is required by $\mathrm{PN}-\mathrm{EN}[7]$.

Table 1. Graph presentation of selected bending eigenforms and eigenfrequencies of the analyzed bridge

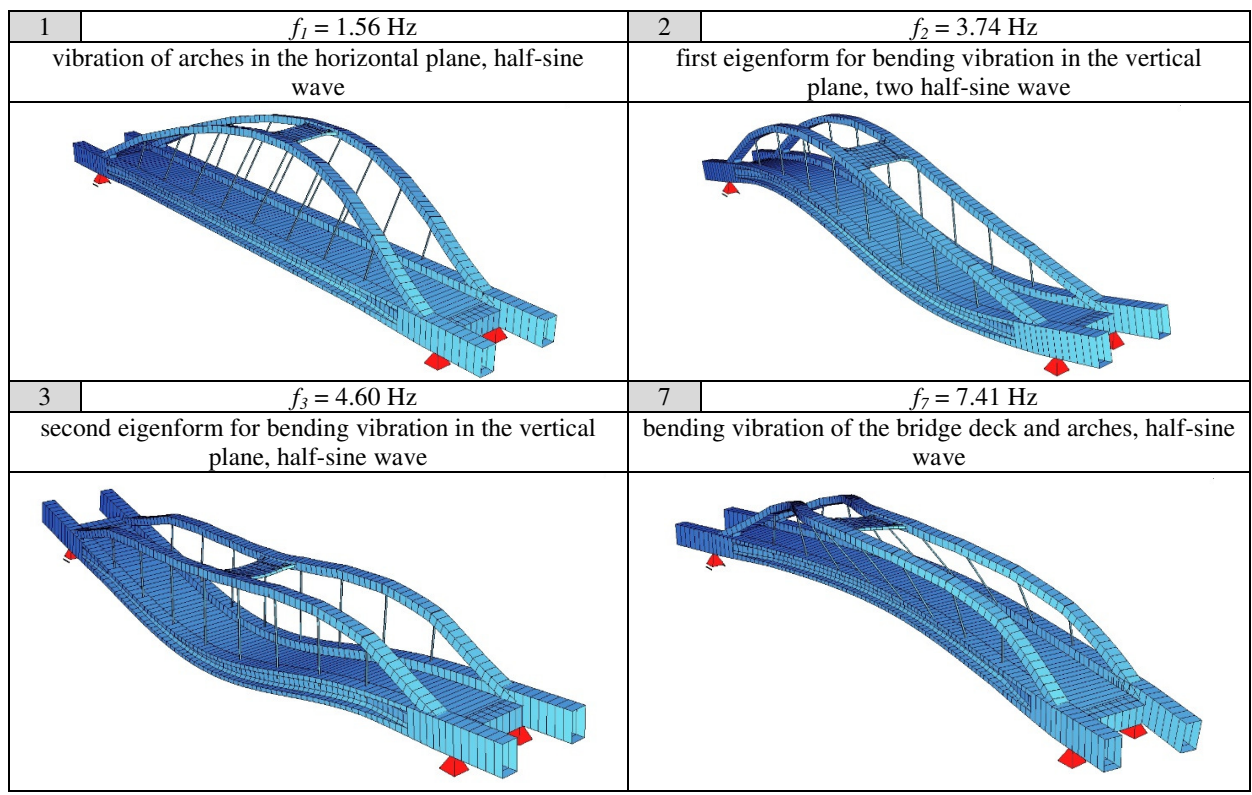


Table 2. Graph presentation of selected torsional eigenforms and eigenfrequencies of the analyzed bridge

\begin{tabular}{|c|c|c|c|}
\hline 1st torsional mode & $f_{4}=5.52 \mathrm{~Hz}$ & 2nd torsional mode & $f_{5}=6.33 \mathrm{~Hz}$ \\
\hline & & & \\
\hline
\end{tabular}

The first torsional mode shape, determined on the basis of the fully detailed shell and beam model $\left(\mathrm{PB}, \mathrm{e}^{1}+\mathrm{e}^{2}, \mathrm{p}^{3}\right)$, is observed at the minimum frequency of $n_{T}=f_{\min }=5.52 \mathrm{~Hz}$. In the simplified, spatial frame model (R3D-2, $\left.\mathrm{e}^{1}, \mathrm{p}^{3}\right)$, the first torsional mode shape is observed at a frequency of $5.47 \mathrm{~Hz}$. The results obtained with the two models differ only by about $1 \%$. In the analyzed arch structure, the ratio of the lowest frequency of torsional vibration to the first frequency of the vertical bending vibration is $n_{T} / n_{0}=5.52 / 3.74=1.47>1.2$, and therefore, according to PN-EN [7], the analyzed bridge is not sensitive to torsional vibration, and for the purpose of time-history analysis these mode shapes are of minor importance.

The minimum frequency of the lateral (horizontal bending) vibration obtained with R3D-3 model is $f_{h \min }=7.41 \mathrm{~Hz}$, which is more than the value of $f_{h 0}=1.2 \mathrm{~Hz}$. Thus, according to PN-EN [7], the structure is also not sensitive to lateral vibration, which may be caused by sidesway, for example.

\subsection{DYNAMIC SYSTEM RESPONSE}

The time-history analysis takes into consideration bending moments $M_{y}$, vertical displacements $u_{z}$, and accelerations $a_{z}$, at the points located on the main girders at about $1 / 4.5(0.22 \cdot \mathrm{L})$ and $1 / 2$ $(0.50 \cdot \mathrm{L})$ of the total span length (Figs. 4 and 5). The relationships between the analyzed parameters $\left(a_{z}, u_{z}, M_{y}\right)$ and running speed and the HSLM-A load model are presented in Figs. $6 \div 8$. 

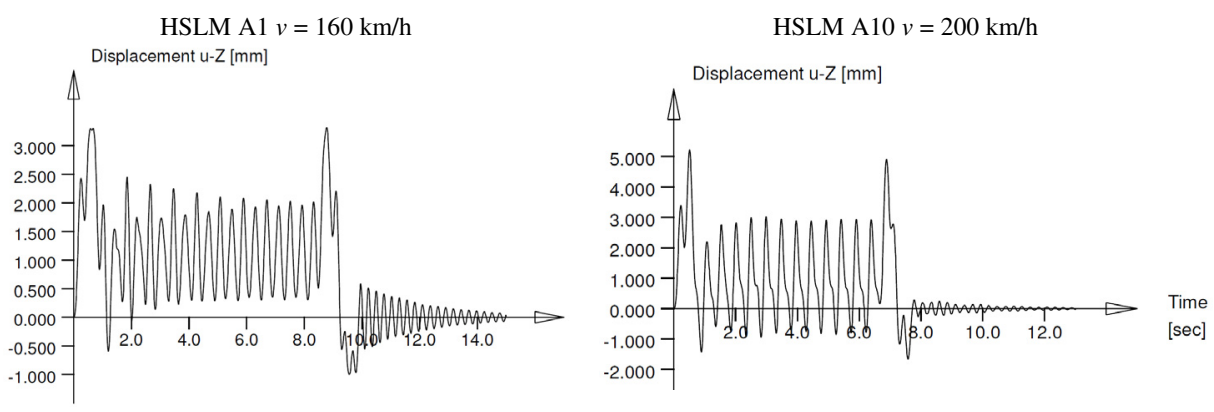

Fig. 4. Selected time-history diagrams of the main girder vertical displacements $u_{z}$ at the node located at $0.22 \cdot \mathrm{L}$ from the support, imposed by the HSLM train set

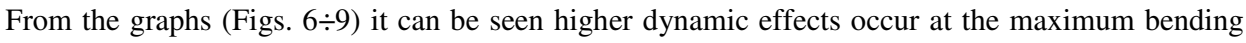
moments at section (ca. $0.22 \cdot \mathrm{L}$ ) at a train speed of about $230 \div 280 \mathrm{~km} / \mathrm{h}$. At that point, certain types of HSLM train sets cause vertical span accelerations $a_{z}$ exceeding the limit value $a_{z d o p}=3.5 \mathrm{~m} / \mathrm{s}^{2}$ set due to risk of ballast instability (Fig. 6). The greatest dynamic effects of high-speed trains were noted at speeds higher than $320 \mathrm{~km} / \mathrm{h}$. As seen in the graph in Fig. 6, the value of acceleration $a_{z}$ at the midspan is below $a_{z d o p}=3.5 \mathrm{~m} / \mathrm{s}^{2}$ for all considered train speeds (they do not exceed $3.0 \mathrm{~m} / \mathrm{s}^{2}$ ). The dynamic effects are the greatest when the train enters onto or leaves the bridge, as represented by the peaks of $u_{z}$ amplitudes (Fig. 4 and Fig. 5). Between these points of time, the vibrations at the section located at $0.22 \cdot \mathrm{L}$, oscillate about the point of equilibrium. As soon as the load leaves the bridge, the vibrations fade out.
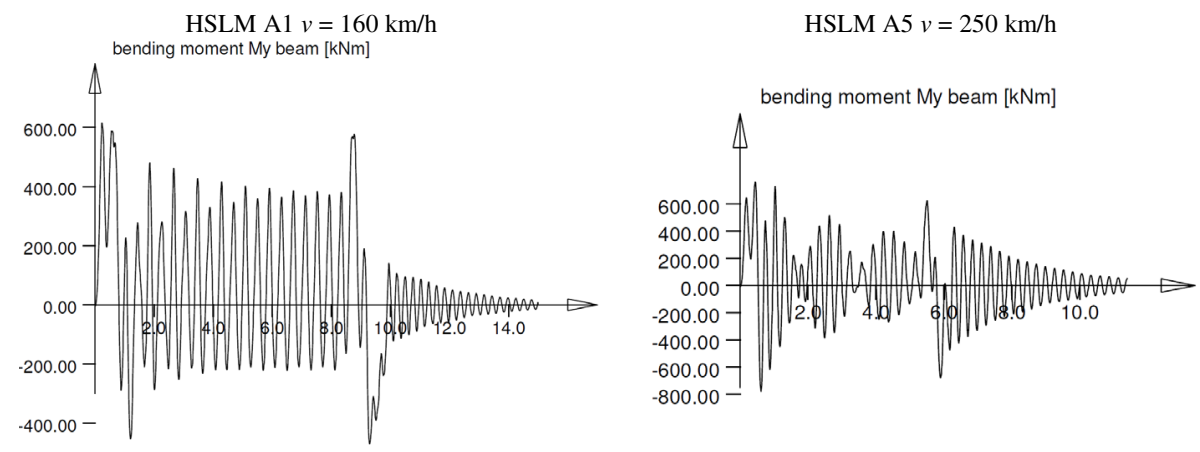

Fig. 5. Selected time-history diagrams of the main girder bending moments $M_{y}[\mathrm{kNm}]$ at the node located at $0.22 \cdot \mathrm{L}$ from the support, imposed by the HSLM train set 


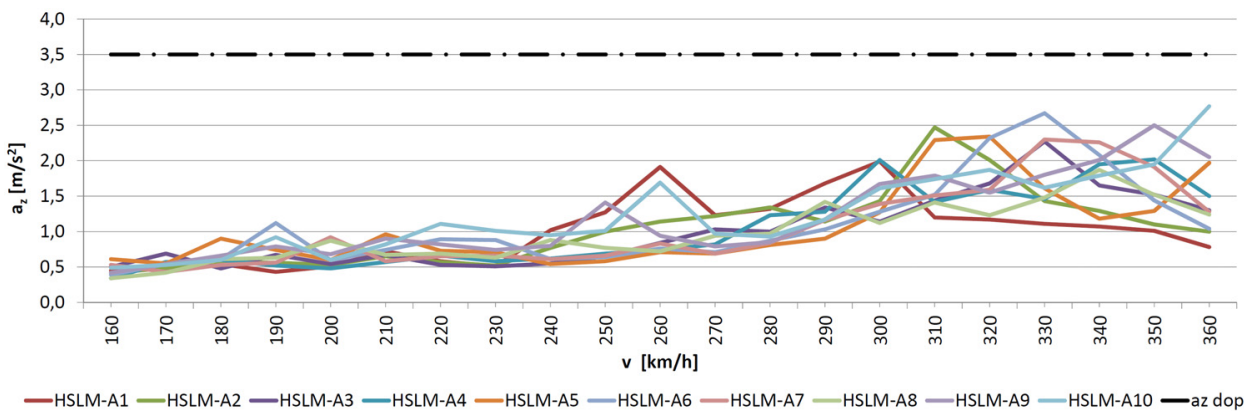

Fig. 6. The main girder vertical acceleration $a_{z}\left[\mathrm{~m} / \mathrm{s}^{2}\right]$ at midspan $(0.50 \cdot \mathrm{L})$ vs. running speed $v[\mathrm{~km} / \mathrm{h}]$ for HSLM A $1 \div \mathrm{A} 10$

Under static loading of the bridge by the HSLM-A train model, the maximum moments are ca. 36 $\%$ for point $0.22 \cdot \mathrm{L}$ and ca. $45 \%$ for point $0.50 \cdot \mathrm{L}$ (of the design moment from $\mathrm{NC}$ class trains) according to $[4,5]$. The maximum dynamic moments from HSLM-A do not exceed the design moments from NC class trains at running speeds of about $230 \div 280 \mathrm{~km} / \mathrm{h}$ and $v>320 \mathrm{~km} / \mathrm{h}$ (Fig. 8).

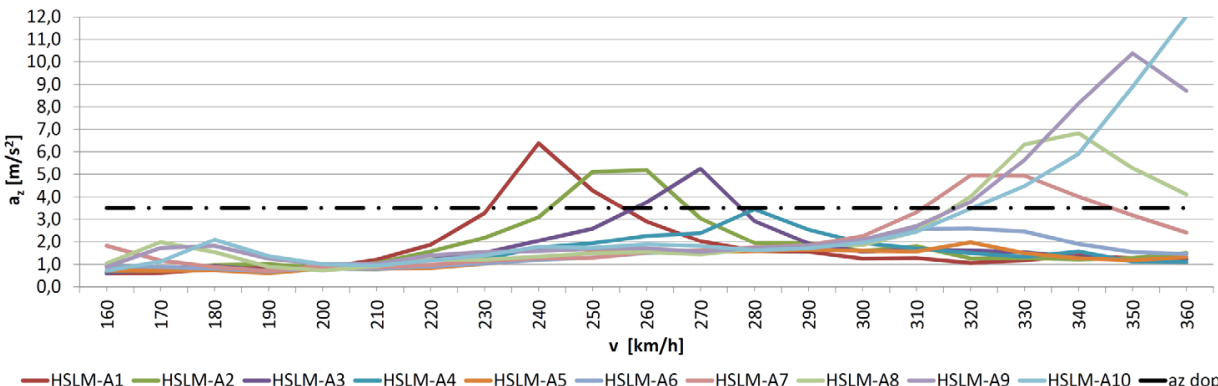

Fig. 7. The main girder vertical acceleration $a_{z}\left[\mathrm{~m} / \mathrm{s}^{2}\right]$ at $0.22 \cdot \mathrm{L}$ from support vs. running speed $v[\mathrm{~km} / \mathrm{h}]$ for HSLM A $1 \div$ A 10 


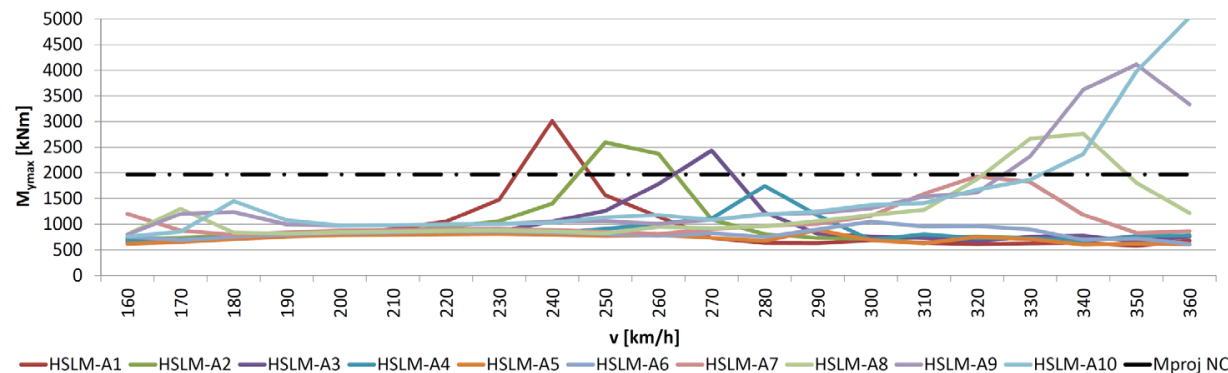

Fig. 8. The main girder bending moments $M_{y}[\mathrm{kNm}]$ at $0.22 \cdot \mathrm{L}$ from support vs. running speed $v[\mathrm{~km} / \mathrm{h}]$ for HSLM A $1 \div \mathrm{A} 10$

Fig. 9 presents the relationship between the dynamic amplification factor vs. midspan deflection and train speed $\varphi=\varphi\left(v, u_{z}\right)$. They are compared to requirements in place at the time of bridge design $[4,5] \varphi_{\text {proj }}=1.212$ and by the PN-EN [7] where $\Phi_{2}=1.140$ for careful maintenance and $\Phi_{3}=1.210$ for standard maintenance of the track. Across the whole range of analysed running speeds of HSLM-A load models, the dynamic amplification factors determined on the basis of the timehistory analysis are in the range of $\varphi\left(v, u_{z}\right)=1.25 \div 2.0$. These values are higher than those calculated according to the standard equations $\left(\varphi_{\mathrm{proj}}=1.212, \Phi_{2}=1.140, \Phi_{3}=1.210\right)$. Already at $v=160 \mathrm{~km} / \mathrm{h}$ the dynamic amplification factor exceeds the design value of $\varphi_{\text {proj }}=1,212$ as per $[4,5]$.

The peaks of the dynamic amplification factors $\varphi\left(v, u_{z}\right)$ occur at speeds of $v=180 \mathrm{~km} / \mathrm{h}(\varphi=1.31), v$ $=260 \mathrm{~km} / \mathrm{h}(\varphi=1.47), v=310 \mathrm{~km} / \mathrm{h}(\varphi=1.75), v=330 \mathrm{~km} / \mathrm{h}(\varphi=1.85)$, and $v=360 \mathrm{~km} / \mathrm{h}(\varphi=$ 2.0). Note that the maximum values of $\varphi\left(v, u_{z}\right)$ are generated at the given speeds by different HSLMA trains. The dynamic heights are the greatest in the case of HSLM-A6 and the lowest in the case of HSLM A1, A2, A3, A9, and A10. Load tests performed before turning the bridge over to public use in 1959 [21] were carried out by loading the bridge with locomotives traveling at much lower speeds of $v_{1}=27 \mathrm{~km} / \mathrm{h}, v_{2}=60 \mathrm{~km} / \mathrm{h}, v_{3}=69 \mathrm{~km} / \mathrm{h}, v_{4}=75 \mathrm{~km} / \mathrm{h}$, and the following dynamic amplification factors were obtained at that time: $\varphi_{1}=1.059, \varphi_{2}=1.125, \varphi_{3}=1.258, \varphi_{4}=1.194\left(\varphi_{\max }\right.$ $=\varphi_{3}=1.258>\varphi_{\text {proj }}=1.212$ ). 


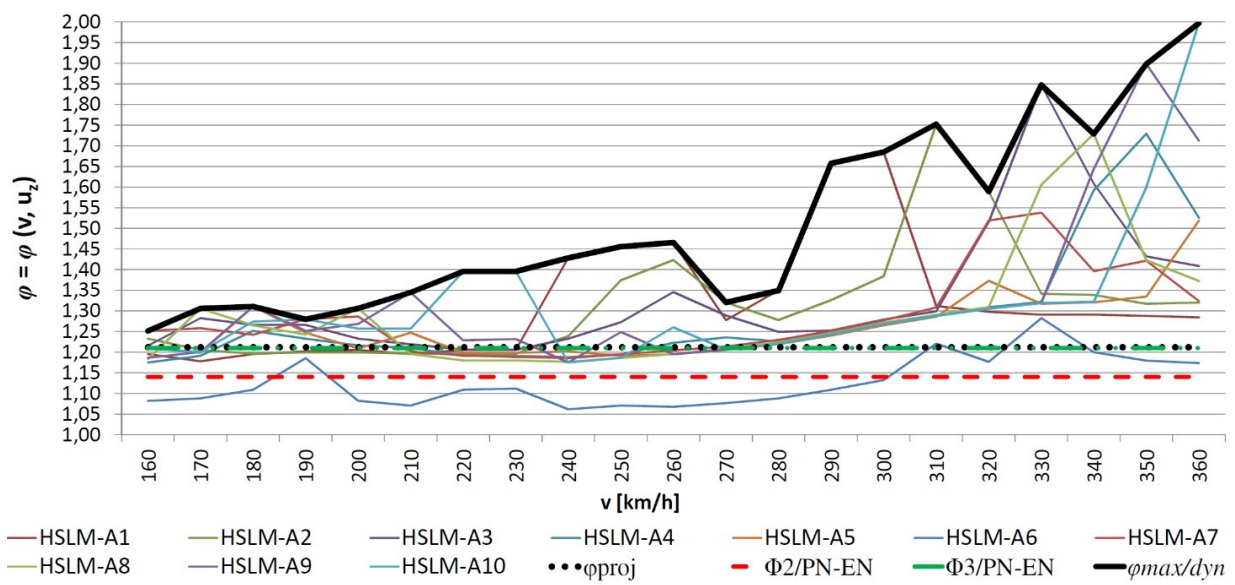

Fig. 9. Dynamic amplification factor $\varphi=\varphi\left(v, u_{z}\right)$ vs. deflections and running speed of HSLM A1-A10 trains

The rules for determining deflection of railway bridge superstructures, described in paragraph A2.4.4.3 of PN-EN [6], are given as meeting the conditions concerning required passenger comfort, which depends on vertical acceleration $b_{v}$ inside the rail-coach. Acceleration $b_{v}$ can be determined based on the analysis of dynamic train-bridge interactions. Such analysis requires application of advanced numerical procedures, presented e.g., in [14], as well as information regarding train characteristics (mass distribution, stiffness, dumping parameters of the railway rolling stock) and information on the visco-elastic characteristics of the railway subgrade. Normally, the above information is not available in the stage of bridge design, and, therefore, in PN-EN 1990 [6] simplified analysis is acceptable. It consists of determining the relation between the allowable deflection of the bridge superstructure $\delta_{d o p}$ corresponding to the given train velocity and the acceleration inside the railway coach $b_{v}$. The above acceleration depends on the level of passenger comfort $\left(b_{v}=1.0 \mathrm{~m} / \mathrm{s}^{2}-\right.$ very good, $b_{v}=1.3 \mathrm{~m} / \mathrm{s}^{2}-\operatorname{good}, b_{v}=2.0 \mathrm{~m} / \mathrm{s}^{2}-$ sufficient $)$. The minimal required level of passenger comfort is determined by the condition $u_{z \max } \leq \delta_{d o p}=\delta_{d o p}(v)$. Static deflections of the bridge superstructure $u_{\max }$ should be no more than $\delta_{d o p}$. The value of $\delta_{d o p}$ depends on span length $L$, train velocity $v$, and the structural system of the bridge (cf. nomograph A2.3. in [6]). The maximum value of deflection of the bridge superstructure $u_{\max }$ can be determined using static loading correspondence to model LM-71 (ULC-71), with its multiplication by dynamic coefficient $\Phi$ and coefficient $\alpha_{k}=1.0$ concerning specified vertical loading (cf. A2.4.4.3.4(2) [6]). The relation between $u_{\max }$ in the middle of the bridge's span under static load from LM-71 $\left(\alpha_{k}=1.0\right.$, $\left.\Phi=\Phi_{3}=1.210\right)$ and the allowable deflection $\delta=\delta(v)$ according to [6], is shown in fig. 10. It can be 
seen that $u_{\max }=15.1 \mathrm{~mm}$ does not exceed the allowable deflection $\delta_{d o p}$ corresponding to train velocity $v<360 \mathrm{~km} / \mathrm{h}\left(b_{v}=1.0 \mathrm{~m} / \mathrm{s}^{2}-\right.$ very good comfort $)$.

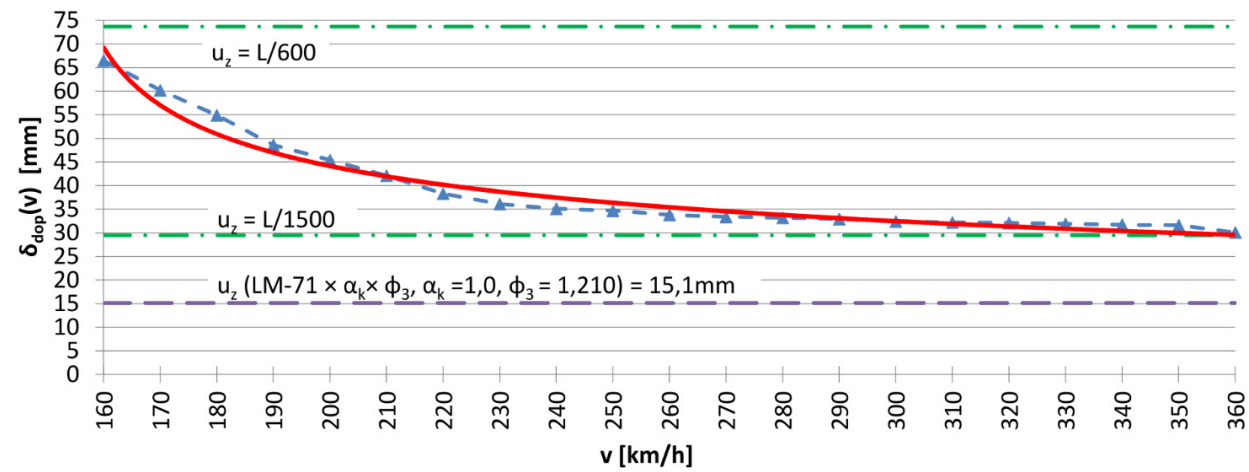

Fig. 10. Allowable deflections $\delta_{\text {dop }}$ of the superstructure under static load by LM-71 vs. train speeds meeting the condition of very good comfort of passengers - according to PN-EN [6]

\section{CONCLUSIONS}

The results of the current dynamic analysis of the Gucin arch bridge allow us to conclude the following:

- in accordance with PN-EN recommendations, the structure is relatively insensitive to torsional mode shapes $\left(n_{T} / n_{0}=1.47>1.2\right)$ and horizontal deck vibration $\left(f_{h}=7.41 \mathrm{~Hz}>1.2 \mathrm{~Hz}\right)$ and these mode shapes are not relevant to the dynamic response analysis (the HSLM load model consists of vertical forces without any load eccentricity),

- the HSLM-A load models generated unacceptable increases in accelerations $a_{z}$, displacements $u_{z}$, and bending moments $M_{y}$ at a speed range of about $230 \div 280 \mathrm{~km} / \mathrm{h}$ and over $320 \mathrm{~km} / \mathrm{h}$,

- passages of HLSM-A trains generate maximum vertical accelerations of $a_{z}>a_{z d o p}=3.5 \mathrm{~m} / \mathrm{s}^{2}$ at speeds of $v>230 \mathrm{~km} / \mathrm{h}$ at ca. $1 / 4.5$ span length $(0.22 \cdot \mathrm{L})$ and this value is unacceptable because of the risk of destabilization of the ballast,

- across the speed range considered in the analysis, i.e. $v=160 \div 360 \mathrm{~km} / \mathrm{h}$, the dynamic amplification factor determined on the basis of dynamic response analysis of the structure under HSLM A1 $\div$ A10 loading exceeds the design value of $\varphi_{\text {proj }}=1.212$ as well as the values 
determined with the empirical relationships defined by PN-EN [7]: $\Phi_{2}=1.140$ for careful maintenance and $\Phi_{3}=1.210$ for standard maintenance of the track,

- deflections $u_{z}=15,1 \mathrm{~mm}$ of the bridge superstructure under its static loading by LM-71 (with $\alpha_{k}$ $=1.0, \Phi=\Phi_{3}=1.210$ ) meet the standard requirements according to A2.4.4.3.2. [6] concerning acceleration $b_{v} \leq 1,0 \mathrm{~m} / \mathrm{s}^{2}$, corresponding to very good passenger comfort with train velocity $v=$ $160 \div 360 \mathrm{~km} / \mathrm{h}$.

In general, it can be concluded on the basis of the simulations with standard load models HSLM A $1 \div$ A 10 at running speeds of $v=160 \div 360 \mathrm{~km} / \mathrm{h}$ that the analyzed arch bridge structure complies with the contemporary dynamic requirements of PN-EN for trains traveling at speeds of $v<230$ $\mathrm{km} / \mathrm{h}$. The dynamic values measured in practice are usually lower than the values estimated in theoretical analyses according to the Eurocodes, which feature a number of simplifications in modeling the train-track-bridge interaction. Some suggestions regarding sophisticated calculation methods are presented, for example, in $[9,11,12,14,19,24,25]$. The procedure presented herein can be applied for estimating the behavior of old bridge structures subjected to high-speed passage of the trains. The analysis presented above is of a numerical nature. The dynamic characteristics of the structure determined according to the Eurocodes are a good illustration of a philosophy of overestimating (conservative) design standards. The most accurate way to calibrate the standard requirements is through testing existing bridge structures which are subjected to real train loading. In the analyzed case, the acceptable train velocity could very well exceed $230 \mathrm{~km} / \mathrm{h}$. However, taking into account all the contemporary requirements, such high train velocities, these are rather not of practical importance.

\section{REFERENCES}

1. Id-2. Technical requirements for railway engineering Structures, PKP, S.A. (in Polish).

2. Technical standards - Detailed technical requirements for modernization and construction of railway lines for service velocity v $\leq 200 \mathrm{~km} / \mathrm{h}$ and $250 \mathrm{~km} / \mathrm{h}$, Warsaw 2010 (in Polish).

3. Technical standards - Detailed technical requirements for modernization or construction of railway line CMK up to the service velocity 200/250 km/h. Engineering structures, CNTK 2002 (in Polish).

4. Technical standard for design of railway bridges D-64. Ministry of Railways, Warsaw 1954 (in Polish).

5. Polish Standard PN-B-02015:1966, Bridges, viaducts and culverts - Loads and actions (in Polish).

6. PN-EN 1990:2004/A1, Basis of structural design, PKN, Warsaw (in Polish).

7. PN-EN 1991-2:2007, Action on structures. Part 2: Traffic loads on bridges, PKN, Warsaw (in Polish).

8. Order of the Ministry of Transport and Maritime Economy dated 10.09.1998, for technical requirements concerning railway engineering structures and their location, Dz. U. no 151 (in Polish).

9. UIC Code 776-2, Design requirements for rail-bridges based on interaction phenomena between train, track and bridge, UIC, 2009.

10. L. Apanas, K. Sturzbecher, "Dynamic analysis of the truss railway viaduct for its accommodation of high velocity trains", AIIL PP 5/2009, pp. 9-33 (in Polish).

11. L. Fryba, "Dynamics of railway bridges", T. Telford, 1996. 
12. J. M. Gicolea, J. Dominiquez, J. A. Navarro, F. Gabaldon, "New dynamic analysis methods for railway bridges in codes IAPF and Eurocode 1", Railway Bridges Design, Construction and Maintenance, Madrid 2002, pp. 143.

13. T. Chmielowski, Z. Zembaty, "Fundamentals of structure dynamics", Arkady, Warsaw 1998 (in Polish).

14. M. Klasztorny, "Dynamics of girder bridges subjected to high velocity train loading", WNT, Warsaw 2006 (in Polish).

15. E. J. O’Brien, L. D. Keogh, "Bridge deck analysis", E \& FN Spon, London 1999.

16. G. Rakowski, Z. Kacprzyk, "MES in Structural Mechanics", Editorial Office of Warsaw University of Technology, Warsaw 2005 (in Polish).

17. W. Siekierski, K. Sturzbecher, "Modernization of composite bridge superstructures for accommodation to high service velocity", XV Seminar „Contemporary methods of bridge strengthening and modernization”, Rosnówko 2005 (in Polish).

18. K. Sturzbecher, "Dynamic analysis of railway bridge superstructures with steel-concrete girders for its accommodation to service velocity of $250-340 \mathrm{~km} / \mathrm{h}$ ", Archives of Institute of civil Engineering, Poznan University of Technology, AIIL PP 4/2008, pp. 161-174 (in Polish).

19. M. Szafrański, K. Żółtowski, "Modeling of Bridge Structures for Dynamic Analysis", Seminar Railway Bridges, Warszawa-Jachranka 2013 (in Polish).

20. W. Trochymiak, R. Oleszek, P. Mossakowski, "Analysis of Railway Bridges made of LW 1200 beams for accommodating the CMK railway line to a high-speed railway", Science Notebooks of Rzeszow University of Technology no 283/2012, pp. 435-443 (in Polish).

21. Z. Wasiutyński, "Selected papers, v. III", Editorial Office of Warsaw University of Technology, Warszawa 1985 (in Polish).

22. H. Zobel, A. Zbiciak, R. Oleszek, R. Michalczyk, P. Mossakowski, "Numerical Identification of The Dynamic Characteristics of a Steel-Concrete Railway Bridge", Roads and Bridges no 13/2014, pp. 275-301. (in Polish and in English).

23. K. Żółtowski , et al., "Reconstruction of the high-speed railway bridge over the Pilica River", Archives of Institute of Civil Engineering, Poznan University of Technology, AIIL PP 4/2010, pp. 289-299 (in Polish).

24. Y. B. Yang, J. D. Yau, Y. S. Wu, "Vehicle-bridge interaction dynamics", Word Scientific Publishing, Singapore 2004.

25. M. Ülker-Kaustell, R. Karoumi, "Influence of non-linear stiffness and damping on train-bridge resonance of a simply supported railway bridge", Engineering Structures, 41/2012, pp. 350-355.

\section{LIST OF FIGURES AND TABLES:}

Fig. 1. Railway bridge over the river Orz in Gucin, Poland: a) cross-section, b) side view

Rys. 1. Most kolejowy nad rzeką Orz w Gucinie: a) przekrój poprzeczny, b) widok z boku

Fig. 2. Graph presentation of the respective numerical models: a) spatial frame model - R3D-3, $\left.\left(e^{1}, p^{3}\right), b\right)$ beam and shell model, PB, $\left(\mathrm{e}^{1}+\mathrm{e}^{2}, \mathrm{p}^{3}\right)$

Rys. 2. Wizualizacja modeli numerycznych konstrukcji: a) prętowa rama przestrzenna - R3D-3, $\left(e^{1}, \mathrm{p}^{3}\right)$,

b) przestrzenna struktura belkowo-powłokowa, $\mathrm{PB},\left(\mathrm{e}^{1}+\mathrm{e}^{2}, \mathrm{p}^{3}\right)$

Fig 3. High-speed train load model HSLM-A according to PN-EN [7]

Rys. 3. Model pociągu szybkobieżnego HSLM-A według PN-EN [7] 
Fig. 4. Selected time-history diagrams of the main girder vertical displacements $u_{z}$ at the node located $0.22 \cdot \mathrm{L}$ from the support, imposed by the HSLM train set

Rys. 4. Wybrane przebiegi czasowe przemieszczeń pionowych $u_{z}$ belki głównej w węźle w odległości $0,22 \cdot \mathrm{L}$ od podpory, wywołane przejazdem pociągów szybkobieżnych HSLM

Fig. 5. Selected time-history diagrams of the main girder bending moments $M_{y}[\mathrm{kNm}]$ at the node located 0.22 $\mathrm{L}$ from the support, imposed by the HSLM train set

Rys 5. Wybrane przebiegi czasowe momentów zginających $M_{y}[\mathrm{kNm}]$ belki głównej w węźle w odległości 0,22 L od podpory, wywołane przejazdem pociągów szybkobieżnych HSLM

Fig. 6. Main girder vertical acceleration $a_{z}\left[\mathrm{~m} / \mathrm{s}^{2}\right]$ at midspan $(0.50 \cdot \mathrm{L})$ vs. running speed $v[\mathrm{~km} / \mathrm{h}]$ for HSLM $\mathrm{A} 1 \div \mathrm{A} 10$

Rys . 6. Zależność przyspieszeń pionowych $a_{z}\left[\mathrm{~m} / \mathrm{s}^{2}\right]$ belki głównej w środku przęsła $(0,50 \cdot \mathrm{L})$ od prędkości ruchu $v[\mathrm{~km} / \mathrm{h}]$ pociągów modelowych HSLM A $1 \div \mathrm{A} 10$

Fig. 7. Main girder vertical acceleration $a_{z}\left[\mathrm{~m} / \mathrm{s}^{2}\right]$ at $0.22 \cdot \mathrm{L}$ from support vs. running speed $v[\mathrm{~km} / \mathrm{h}]$ for HSLM A $1 \div$ A 10

Rys. 7. Zależność przyspieszeń pionowych $a_{z}\left[\mathrm{~m} / \mathrm{s}^{2}\right]$ belki głównej w odległości $0,22 \cdot \mathrm{L}$ od podpory od prędkości ruchu $v[\mathrm{~km} / \mathrm{h}]$ pociągów modelowych HSLM A1 $\div$ A10

Fig. 8. Main girder bending moments $M_{y}[\mathrm{kNm}]$ at $0.22 \cdot \mathrm{L}$ from support vs. running speed $v[\mathrm{~km} / \mathrm{h}]$ for HSLM A $1 \div \mathrm{A} 10$

Rys. 8. Zależność momentów zginających $M_{y}[\mathrm{kNm}]$ belki głównej w odległości $0,22 \cdot \mathrm{L}$ od podpory od prędkości ruchu $v[\mathrm{~km} / \mathrm{h}]$ pociągów modelowych HSLM A1 $\div$ A 10

Fig. 9. Dynamic amplification factor $\varphi=\varphi\left(v, u_{z}\right)$ vs. deflections and running speed of HSLM A1-A10 trains Rys. 9. Wykres współczynnika dynamicznego $\varphi=\varphi\left(v, u_{z}\right)$ w funkcji ugięć i prędkości ruchu pociągów szybkobieżnych HSLM A $1 \div$ A10

Fig.10 Allowable deflections $\delta_{\text {dop }}$ of the superstructure under static load by LM-71 vs. train speeds meeting the condition of very good passenger comfort - according to PN-EN [6]

Rys. 10. Dopuszczalne ugięcia przęsła $\delta_{d o p}$ od modelu obciążenia statycznego LM-71 w funkcji prędkości ruchu pociągów przy bardzo dobrym komforcie pasażerów obliczone według PN-EN [6]

Table 1. Graph presentation of selected bending eigenforms and eigenfrequencies of the analysed bridge Tabela 1. Wizualizacja wybranych częstotliwości i form giętnych drgań własnych mostu

Table 2. Graphical presentation of selected torsional eigenforms and eigenfrequencies of the analysed bridge Tabela 2.Wizualizacja wybranych częstotliwości i form skrętnych drgań własnych mostu 


\section{ANALIZA DYNAMICZNA ISTNIEJĄCEGO ŁUKOWEGO MOSTU KOLEJOWEGO WEDŁUG EUROKODÓW}

Stowa kluczowe: most łukowy, beton sprężony, pociągi szybkobieżne, HSLM, analiza dynamiczna,

\section{STRESZCZENIE:}

Współczesne przepisy kolejowe $[1 \div 3,8]$ bazują na Eurokodach [6, 7], w których dynamiczny charakter obciążenia uwzględniany jest na podstawie analizy dynamicznej odpowiedzi konstrukcji z symulacją ruchu obciążenia. Polega ona na wyznaczeniu bezpośrednich procesów deformacji i dystrybucji sił wewnętrznych i naprężeń od modelowych obciążeń pociągami szybkobieżnymi HSLM (High Speed Load Model). W referacie przedstawiono wyniki teoretycznej analizy oddziaływania modeli pociągów szybkobieżnych HSLM-A pod kątem wymagań PN-EN, na konstrukcję pierwszego wybudowanego w Polsce (1959 r.) łukowego mostu kolejowego z betonu sprężonego.

Most nad rzeką Orz w Gucinie (rys. 1) jest pierwszym w Polsce zastosowaniem kablobetonu w łukowym obiekcie kolejowym, zaprojektowanym w latach 1955 1956 przez zespół prof. Zbigniewa Wasiutyńskiego w II Katedrze Budowy Mostów Politechniki Warszawskiej, a wybudowanym w latach 1956-1959 [21].

Modele obliczeniowe konstrukcji wykonano w środowisku MES SOFiSTiK [15, 16, 19, 22]. Analizę modalną (rozwiązanie zagadnienia własnego) przeprowadzono w module ASE. W obliczeniach drgań własnych uwzględniono ciężary elementów niekonstrukcyjnych (wyposażenie - podsypka tłuczniowa, podkłady, szyny), dokonując konwersji tych obciążeń na równoważne masy węzłowe. Obliczenia globalnej (pominięto drgania wieszaków) dynamicznej odpowiedzi konstrukcji (analiza czasowa) przeprowadzono w module DYNA systemu SOFiSTiK. Wykorzystano algorytm niejawnego numerycznego całkowania równań ruchu Newmarka ("time step") [11 13, 14, 16, 24]. Model obciążenia normowymi pociągami HLSM A1 $\div$ A10 przyjęto w postaci strumieni sił skupionych [11, 12, 19, 24].

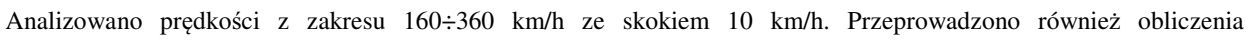
"przejazdów (ustawień) statycznych" obciążenia po konstrukcji. Umożliwia to porównanie efektów dynamicznych i statycznych oraz określenie współczynnika dynamicznego $\varphi=\varphi\left(v, u_{z}\right)$.

W rozpatrywanej konstrukcji łukowej stosunek najniższej częstotliwości drgań skrętnych mostu do pierwszej częstotliwości drgań giętnych pionowych wynosi $n_{T} / n_{0}=5,52 / 3,74=1,47>1,2$. Oznacza to, że w świetle PN-EN [7] analizowany most jest niewrażliwy na drgania skrętne $\mathrm{i}$ w analizie czasowej te formy mają mniejsze znaczenie. Minimalna częstotliwość drgań bocznych (giętnych poziomych) uzyskana z Modelu R3D-3 wynosi $f_{\text {hmin }}=7,41 \mathrm{~Hz}>f_{h 0}$ = 1,2 Hz. W świetle PN-EN konstrukcja jest nie wrażliwa na drgania boczne (wywołane np. wężykowaniem taboru).

W analizie czasowej rozpatrywano przebiegi czasowe momentów zginających $M_{y}$, przemieszczeń pionowych $u_{z} \mathrm{i}$ przyspieszeń $a_{z}$ punktów w dźwigarach głównych zlokalizowanych w około 1/4,5 $(0,22 \cdot \mathrm{L})$ i 1/2 $(0,50 \cdot \mathrm{L})$ rozpiętości przęsła. Przykłady zależności analizowanych wielkości $\left(a_{z}, u_{z}, M_{y}\right)$ od prędkości ruchu i konkretnych typów pociągów HSLM-A przedstawiono w referacie.

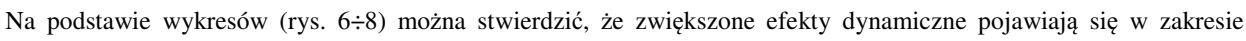
prędkości około $230 \div 280 \mathrm{~km} / \mathrm{h}$, w strefie maksymalnych momentów zginających $(\sim 0,22 \cdot \mathrm{L})$. W tym punkcie przyspieszenia pionowe przęseł $a_{z}$, od niektórych typów pociągów HSLM, przekraczają wartość graniczną $a_{z d o p}=3,5$ $\mathrm{m} / \mathrm{s}^{2}$ z uwagi na rozluźnienie podsypki. Największe dynamiczne oddziaływania pociągów szybkobieżnych dotyczą prędkości $v>320 \mathrm{~km} / \mathrm{h}$. W połowie przęsła przyspieszenia $a_{z}$ są mniejsze od $a_{z d o p}=3,5 \mathrm{~m} / \mathrm{s}^{2}$ dla wszystkich rozpatrywanych prędkości (nie przekraczają $3,0 \mathrm{~m} / \mathrm{s}^{2}$ ). Maksymalne momenty od statycznych ustawień pociągów 
HSLM-A wynoszą w punkcie $0,22 \cdot \mathrm{L}$ około $36 \%$, natomiast w punkcie $0,50 \cdot \mathrm{L}$ około $45 \%$ momentu projektowego od klasy NC według [4, 5]. Maksymalne momenty dynamiczne od HSLM-A przekraczają wartości momentów projektowych od klasy NC przy prędkościach $v \approx 230 \div 280 \mathrm{~km} / \mathrm{h}$ oraz $v>320 \mathrm{~km} / \mathrm{h}$.

W całym zakresie rozpatrywanych prędkości ruchu pociągów modelowych HSLM-A współczynniki dynamiczne określone na podstawie analizy czasowej mieszczą się w zakresie $\varphi\left(v, u_{z}\right)=1,25 \div 2,0$. Są większe niż wartości oszacowane na podstawie wzorów normowych $\left(\varphi_{\text {proj }}=1,212, \Phi_{2}=1,140, \Phi_{3}=1,210\right)$. Już przy prędkości $v=160 \mathrm{~km} / \mathrm{h}$ współczynnik dynamiczny przekracza wartość projektową $\varphi_{\text {proj }}=1,212$ według $[4,5]$.

Lokalne ekstrema współczynników dynamicznych $\varphi\left(v, u_{z}\right)$ występują przy prędkościach $v=180 \mathrm{~km} / \mathrm{h}(\varphi=1,31), v=$ $260 \mathrm{~km} / \mathrm{h}(\varphi=1,47), v=310 \mathrm{~km} / \mathrm{h}(\varphi=1,75), v=330 \mathrm{~km} / \mathrm{h}(\varphi=1,85)$ i $v=360 \mathrm{~km} / \mathrm{h}(\varphi=2,0)$. Wartości maksymalne współczynników $\varphi\left(v, u_{z}\right)$ generowane są przy podanych prędkościach przez różne pociągi z grupy HSLM-A. Najmniejsze przewyższenia dynamiczne generuje pociąg HSLM-A6, natomiast największe powodują modele HSLM A1, A2, A3, A9 i A10. Podczas badań odbiorczych mostu w 1959 roku [21], obciążonego parowozami poruszającymi się ze znacznie mniejszymi prędkościami $v_{1}=27 \mathrm{~km} / \mathrm{h}, v_{2}=60 \mathrm{~km} / \mathrm{h}, v_{3}=69 \mathrm{~km} / \mathrm{h}, v_{4}=75 \mathrm{~km} / \mathrm{h}$, pomierzono następujące odpowiadające wartości współczynników dynamicznych $\varphi_{1}=1,059, \varphi_{2}=1,125, \varphi_{3}=1,258, \varphi_{4}=1,194$ $\left(\varphi_{\max }=\varphi_{3}=1,258>\varphi_{\text {proj }}=1,212\right)$.

W świetle zaleceń PN-EN konstrukcja charakteryzuje się małą wrażliwością na skrętne formy drgań $\left(n_{T} / n_{0}=1,47>1,2\right)$ oraz na drgania poziome pomostu $\left(f_{h}=7,41 \mathrm{~Hz}>1,2 \mathrm{~Hz}\right)$. W analizie odpowiedzi dynamicznej konstrukcji te formy nie mają znaczenia (modele HSLM to pakiety sił pionowych, nie występują mimośrody). Modele pociągów szybkobieżnych HSLM-A powodują nieakceptowane zwiększenie wartości przyspieszeń $a_{z}$, przemieszczeń $u_{z} \mathrm{i}$ momentów zginających $M_{y}$ w dwóch zakresach prędkości $v \approx 230 \div 280 \mathrm{~km} / \mathrm{h}$ oraz przy $v>320 \mathrm{~km} / \mathrm{h}$. Przejazdy pociągów HLSM-A wzbudzają w około 1/4,5 rozpiętości przęsła $(0,22 \cdot \mathrm{L})$ maksymalne przyspieszenia pionowe $a_{z}>$ $a_{z d o p}=3,5 \mathrm{~m} / \mathrm{s}^{2}$ przy prędkości $v>230 \mathrm{~km} / \mathrm{h}$, jest to niedopuszczalne $\mathrm{z}$ uwagi na ryzyko rozluźnienia podsypki. W zakresie rozpatrywanych prędkości $v=160 \div 360 \mathrm{~km} / \mathrm{h}$ współczynnik dynamiczny, określony na podstawie analizy dynamicznej odpowiedzi konstrukcji obciążonej normowymi modelami pociągów szybkobieżnymi HSLM A1 $\div$ A 10 , przewyższa wartość $\mathrm{z}$ okresu projektowania mostu $\varphi_{\text {proj }}=1,212$ oraz określone według PN-EN na podstawie empirycznych zależności $\Phi_{2}=1,140 \mathrm{~W}$ przypadku starannie utrzymywanego toru i $\Phi_{3}=1,210 \mathrm{~W}$ odniesieniu do standardowego utrzymania toru.

Generalnie, przeprowadzone symulacje oddziaływania normowych modeli pociągów szybkobieżnych HSLM-A1 $\div$ A 10 poruszających się z prędkościami $v=160 \div 360 \mathrm{~m} \mathrm{~km} / \mathrm{h}$, świadczą o tym, że analizowana konstrukcja łukowa spełnia wymagania dynamiczne postawione w PN-EN w przypadku prędkości $v<230 \mathrm{~km} / \mathrm{h}$. W rzeczywistych obiektach pomierzone wielkości dynamiczne są zazwyczaj mniejsze niż oszacowane na podstawie analiz teoretycznych według Eurokodów, w których zawarto szereg uproszczeń w modelowaniu interakcji most-tor-pociąg. Przedstawione badania mają charakter symulacji numerycznej. Poprawę zbieżności obliczeń i zachowania się konstrukcji można uzyskać stosując w analizach zidentyfikowany w badaniach terenowych moduł sprężystości betonu oraz liczbę tłumienia. Takie podejście, umożliwiłoby prawdopodobnie zwiększenie zakresu dopuszczalnych prędkości ruchu pociągów. Jednakże, biorąc pod uwagę wszystkie współczesne wymagania dotyczące mostów i linii kolejowych, tak wysokie prędkości nie mają raczej znaczenia praktycznego. Przykłady innych zaawansowanych metod obliczeniowych przedstawiono, między innymi, w pracach $[9,11,12,14,19,24,25]$. 
